\title{
MICROPHYTOBENTHIC BIOMASS ON A SUBTROPICAL INTERTIDAL FLAT OF PARANAGUÁ BAY (SOUTHERN BRAZIL): SPATIO-TEMPORAL DISTRIBUTION AND THE INFLUENCE OF ENVIRONMENTAL CONDITIONS
}

\author{
Alessandra Larissa D'Oliveira Fonseca ${ }^{1, *}$, Eunice da Costa Machado ${ }^{2}$, \\ Frederico Pereira Brandini ${ }^{3}$ and Nilva Brandini ${ }^{4}$ \\ ${ }^{1}$ Universidade Federal de Santa Catarina - Departamento de Geociências \\ Centro de Filosofia e Ciências Humanas \\ (Campus Universitário Trindade, 88040-970 Florianópolis, SC, Brasil) \\ ${ }^{2}$ Centro de Estudos do Mar - Universidade Federal do Paraná \\ (Av. Beira Mar, s/n, 83255-976 Pontal do Paraná, PR, Brasil) \\ ${ }^{3}$ Instituto Oceanográfico da Universidade de São Paulo \\ (Praça do Oceanográfico, 191, 05508-120 São Paulo, SP, Brasil) \\ ${ }^{4}$ Universidade Federal Fluminense - Instituto de Química \\ (Outeiro São João Baptista, s/n, 24020-007 Niterói, RJ, Brasil) \\ *Corresponding author: alarissa.fonseca@gmail.com
}

\begin{abstract}
A B S T R A C T
Seasonal and spatial dynamics of the microphytobenthic biomass on a subtropical intertidal sand flat ( $25^{\circ} 32^{\prime}$ S; $\left.48^{\circ} 24^{\prime} \mathrm{W}\right)$ was investigated monthly from September 1995 to July 1996. Chlorophyll-a and Phaeophytin- $a$ contents, temperature, salinity, inorganic nitrogen and phosphate pore water concentrations and sediment characteristics were assessed in the upper (HW), middle (MW) and lower (LW) sections of the flat. Microphytobenthic biomass content showed a conspicuous seasonal and spatial gradient. Higher chlorophyll- $a$ contents were registered in the HW section of the tidal flat (from $11.78 \mu \mathrm{g} . \mathrm{gsed}^{-1}$ to $38.18 \mu \mathrm{g}$.gsed ${ }^{-1}$ ) decreasing towards the LW section (from $6.23 \mu \mathrm{g} . \mathrm{gsed}^{-1}$ to $\left.18.23 \mu \mathrm{g} . \mathrm{gsed}^{-1}\right)$. Microphytobenthic seasonality was determined mainly by turbulence of the water column, which was influenced by atmospheric events. The sediment properties and nutrient concentrations had a significant effect on the spatial and seasonal distribution of pigments on the intertidal flat.
\end{abstract}

\section{RESUMO}

A dinâmica sazonal e espacial da biomassa microfitobêntica em uma planície arenosa intermareal $\left(25^{\circ} 32^{\prime} \mathrm{S} ; 48^{\circ} 24^{\prime} \mathrm{W}\right)$ foi investigada mensalmente de setembro de 1995 a julho de 1996 . A concentração de clorofila- $a$ e feofitina- $a$, a temperatura, salinidade, concentração de nitrogênio inorgânico e fosfato na água intersticial, além das características do sedimento, foram inferidas na região superior (HW), mediana (MW) e inferior (LW) da planície. A biomassa microfitobêntica apresentou gradientes sazonal e espacial bem definidos. Maiores concentrações de clorofila-a foram registradas na região superior da planície entre marés (HW, de $11.78 \mu \mathrm{g}_{\text {gsed }} \mathrm{gse}^{-1}$ até $38.18 \mu \mathrm{g} . \mathrm{gsed}^{-1}$ ), decrescendo em direção a região inferior da planície ( $\mathrm{LW}$, de $6.23 \mu \mathrm{g} \cdot \mathrm{gsed}^{-1}$ a $18.23 \mu \mathrm{g}_{\mathrm{gsed}} \mathrm{gs}^{-1}$. A sazonalidade microfitobêntica foi determinada principalmente pela turbulência da coluna de água, influenciada pelos eventos atmosféricos. As propriedades do sedimento e as concentrações de nutrientes foram significantes para a distribuição espacial e sazonal dos pigmentos na planície entre marés.

Descriptors: Nutrients, Sediment properties, Pigment content, Benthic microalgae.

Descritores: Nutrientes, Propriedades do sedimento, Conteúdo de pigmentos, Microalga bêntica.

\section{INTRODUCTION}

Tidal variation is an important factor in the physical control of intertidal flats, exposing the system to the air at low tide and to the estuarine aqueous conditions during immersion. Along the intertidal flat, different zones are characterised according to the hydrodynamics, tidal range, slope and habitat sequence (REISE, 1985; DYER et al., 2000). Consequently, the upper, middle and lower flats can 
be distinguished by sediment granulometry and composition that are reflected in the biological community and related biochemical processes (DYER et al., 2000; MUROLO et al., 2006; FONSECA et al., 2008).

These flats contribute substantially to the overall primary production and act as depositional environments trapping organic materials derived from the estuary. These materials are directly utilised by invertebrates and are thus remineralised by biogeochemical microbial processes (MIDDELBURG et al., 2000; CHOY et al., 2008; DU et al., 2010). In tropical and subtropical regions, the main primary producers in the intertidal flats are salt marshes, mangroves and microphytobenthos. However, microalgae are mandatory to the local food chain because they are palatable and rapidly utilised by the meio- and macrobenthos (UNDERWOOD and PATERSON, 1993; HERMAN et al., 2000; WELKER et al., 2002).

The seasonality of benthic communities of tropical and subtropical zones is strongly influenced by the rainfall regime (ALONGI, 1990). The increase of runoff causes erosion and resuspension of the sediments, which destabilises the benthic community. The same physical effect has been observed for microphytobenthic cells during conditions of high wind (DE JONGE and VAN BEUSEKMAN, 1995). Additionally, herbivory, luminosity and nutrients might play important roles in controlling the microphytobenthos, dampening the biomass and reducing primary production rates (REISE, 1992; UNDERWOOD and PATERSON, 1993; SANTOS et al., 1995; MUROLO et al., 2006; YAMAGUCHI et al., 2007; CHOY et al., 2008; DU et al., 2010).

Despite the importance of the microphytobenthic community to the intertidal system, the dynamics of these organisms are poorly understood in the Brazilian estuarine intertidal flat (MUROLO et al., 2006). In this study, there are three hypotheses to be tested: (1) that the microphytobenthos biomasses vary spatially and temporally in a subtropical intertidal flat; (2) if this is true, the spatial variability is determined by the physical (sediment characteristics) and chemical (nutrients concentrations) conditions of the area; and (3) the seasonality is influenced mainly by the rainfall regime.

\section{Material And Methods}

Study Area

The estuarine complex of Paranaguá Bay occupies an area of $612 \mathrm{~km}^{2}$ of the southeastern Brazilian Coast $\left(25^{\circ} 03^{\prime} \mathrm{S}, 48^{\circ} 24^{\prime} \mathrm{W}\right)$ and the area above the 1 metre isobath comprises $132 \mathrm{~km}^{2}$
(NOERNBERG et al. 2006). The eastern portion of the bay is dominated by water from the adjacent continental shelf, whereas the western sector receives greater fluvial influence. The average freshwater input varies from $40 \mathrm{~m}^{3} \cdot \mathrm{s}^{-1}$ in the dry winter period to 200 $\mathrm{m}^{3} \cdot \mathrm{s}^{-1}$ in the rainy summer period (MANTOVANELLI et al., 2004). Similarly, the average salinity values vary from 29 to 12 (MACHADO et al., 1997).

The tidal flats in Paranaguá Bay are large and surrounded by mangrove swamps, salt marshes and unvegetated banks. The dynamics of these systems are strongly influenced by tidal currents, which surpass the effect of fluvial fluxes (BIGARELLA et al., 1978). Tides are semidiurnal and have diurnal inequalities with a mean range of $2.2 \mathrm{~m}$ (MARONE and CAMARGO, 1994). Mainly in winter, strong winds from the southern quadrant amplify the tides, which enhances erosion processes (MARONE and CAMARGO, 1994). The tidal flats occupy an area of $136 \mathrm{~km}^{2}$, which represents $25 \%$ of the water body area of the estuary (NOERNBERG et al., 2006)

This study was undertaken on an intertidal flat in Rasa da Cotinga island, a quasi-pristine system located at the euhaline high-energy site of the Paranaguá Bay. The local flat has a width of about 500 $\mathrm{m}$ from the salt marsh belt to the lower spring tide level. Three equidistant sampling areas were considered along a transect drawn over the lower (LW), middle (MW) and upper (HW) flat, each one occupying an extension of $150 \mathrm{~m}$ (Fig. 1). The sediments are mainly well-sorted fine sands with low organic content in the upper area and well-developed aggregates of shell fragments in the lower area (PAGLIOSA and LANA, 2005). During high tides, the depth of the water column above the intertidal flat varies from 1 to $2 \mathrm{~m}$. Therefore, at high tide, the light that reaches the sediment on the upper and middle flat is more intense than that on the lower flat. This is an important factor in the spatial differences found in the microphytobenthic primary production measured along this flat (FONSECA et al., 2008).

\section{Sampling and Analyses}

Monthly sampling was carried from September 1995 to July 1996. Three equidistant sites were fixed on the LW, MW and HW for the collection of samples for measuring the sediment (grain size, carbonate and organic matter contents), the pore water (temperature, salinity and inorganic dissolved nutrients) characteristics and the microphytobenthic biomass. The sediment samples were collected manually to a depth of $5 \mathrm{~cm}$ by PVC corer $(10 \mathrm{~cm}$ internal $\varnothing$ ) and were kept in black plastic bags and at low temperature until reaching the laboratory. The homogenised sediment was used to determine its 
granulometry, organic matter and carbonate contents (SUGUIO, 1973). Temperature was measured directly in the sediment by standard chemical thermometer. Pore waters were sampled by plastic syringe attached to a disposable filtration system and silicone tube, which was buried up to $2 \mathrm{~cm}$ deep in the sediment. The syringe plunger was pulled up smoothly to fill the volume of $5 \mathrm{~mL}$. This procedure was repeated in different portions of the sampling station until a total sample of $20 \mathrm{~mL}$ was obtained. The salinity was measured by manual refractometer (ATAGO mod. $\mathrm{s} /$ Mill). The pore water sample was stored in a clean polycarbonate bottle, which was kept in the dark at low temperature for two hours at the most. In the laboratory, the sample was filtered and stored in a freezer until analysis (GRASSHOFF et al., 1983). The inorganic nutrient concentrations (phosphate, ammonium, nitrate plus nitrite) were measured in accordance with GRASSHOFF et al. (1983). Dissolved inorganic nitrogen (DIN) was determined by the sum of nitrogen forms.

Sediment triplicates to determine the microphytobenthic biomass were sampled at each station by hand with a black polycarbonate corer $(2 \mathrm{~cm}$ internal $\varnothing)$ that was closed immediately. These samples were transported to the laboratory in a cooling box and immediately frozen at $-20^{\circ} \mathrm{C}$ until further processing. Pigments were extracted with $10 \mathrm{~mL}$ acetone $(100 \%)$ for $24 \mathrm{~h}$ in the dark at $4^{\circ} \mathrm{C}$. The extract was carefully transferred to centrifuge tubes and centrifuged at $4000 \mathrm{rpm}$ for $5 \mathrm{~min}$. The microphytobenthic biomass, chorophyll- $a$ and phaeophytin- $a$ were determined spectrophotometrically (Micronal B380) in accordance with PLANTE-CUNY (1978).

Rainfall and wind data were provided by the meteorological station of the Centro de Estudos do Mar - Universidade Federal do Paraná, located near Rasa da Cotinga island. The direction and velocity of the winds were collected from November 1995 onwards; a data gap occurred before this month.

\section{Data Analyses}

Principal component analysis (PCA, using mean values of each area, $\mathrm{n}=36$ ) were applied to environmental and biotic data (microphytobenthic biomass), data were $4^{\text {th }}$ root transformed. Simple linear correlation (Pearson $r$ ) was performed to measure the relation between variables, using the data for all sampling stations and periods $(n=108 ; \mathrm{p}<0.05)$.

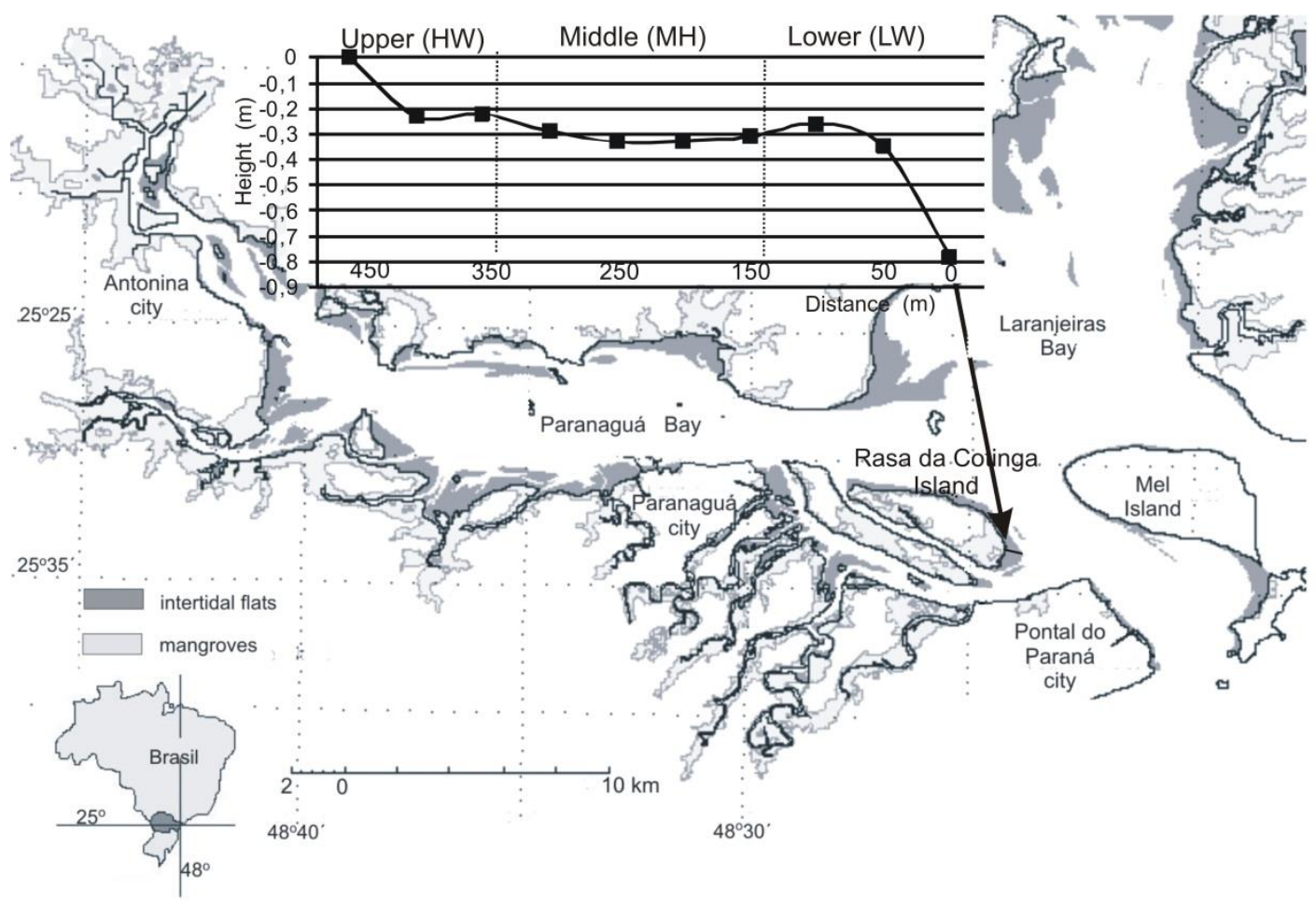

Fig. 1. Intertidal flats of the Paranaguá Bay (dark gray). The transect profile and the location of the sampling areas (HW, MW and LW) on the intertidal flat of Rasa da Cotinga island. (Modified from NOERNBERG et al., 2006). 
A Pejrup granulometric diagram considers the ratio of the sediment fractions (silt/clay/sand) to characterise the hydrodynamic regime of estuarine sediments (PEJRUP, 1988; FLEMMING, 2000). The granulometric data of the sediment were applied to the Pejrup diagram using SysGran 2.0 (CAMARGO, 2006).

\section{Results}

\section{Environmental Conditions}

The rainfall period occurred during summer, from December 1995 to the beginning of May 1996. The maximum daily precipitation $(121 \mathrm{~mm})$ was observed during the week of the May sampling. The rainfall decreased over the rest of the year, especially during the winter (Fig. 2). Moderate $\left(1.6 \pm 0.5 \mathrm{~m} . \mathrm{s}^{-1}\right.$, mean \pm SD) southeasterly and easterly winds dominated throughout the study period. Strong winds were detected from the south $\left(8.5 \mathrm{~m} . \mathrm{s}^{-1}\right.$, December $\left.29^{\text {th }}, 1995\right)$ when a frontal polar mass hit the region (Fig. 2). Strong winds (> $6.0 \mathrm{~m} . \mathrm{s}^{-1}$ ) from the south quadrant were observed occasionally in December 1995 and February and March 1996. During winter 1996 , southerly winds were more frequent; however, their intensity was about $2.0 \mathrm{~m} \cdot \mathrm{s}^{-1}$.
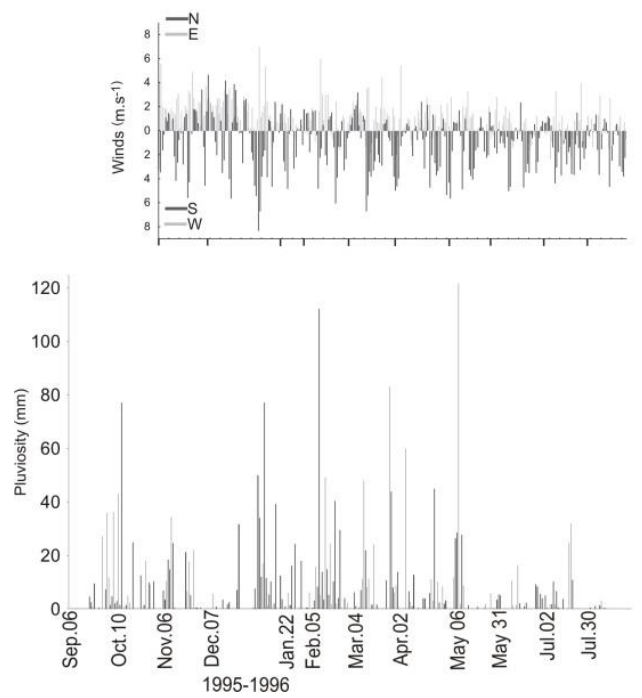

Fig. 2. Intensity $\left(\mathrm{m} \cdot \mathrm{s}^{-1}\right)$ and direction of the winds and the daily precipitation $(\mathrm{mm})$ in the eurihaline sector of the Paranaguá Bay through the study period (from Sep/95 to $\mathrm{Jul} / 96)$. The informations of the winds were measured from Nov/95 to Jul/96.

\section{Sediment Characteristics}

The intertidal flat was characterized by fine sand (from poorly to moderately sorted) at LW and by very fine sand (from poorly to well sorted) at MW and HW (Fig. 3). The sand contents were quite homogeneous along the flat, ranging from $81 \% \pm 1 \%$ to $93 \% \pm 1 \%($ mean $\pm \mathrm{SD})$. The $\mathrm{LW}$ had the highest gravel content $(5 \% \pm 0.5 \%)$, which decreased to the middle $(2 \% \pm 0.4 \%)$ and upper $(0.8 \% \pm 0.5 \%)$ areas. A slight spatial gradient of organic matter content was observed (Fig. 4), increasing from LW (1.3\%) to HW $(2.6 \%)$. The sediment organic matter content increased from December-Summer ( $1.3 \%$ to $1.7 \%)$ to JulyWinter $(1.8 \%$ to $2.6 \%)$. Carbonate showed an inverse spatial pattern to that of organic matter (Fig. 4), decreasing from LW (16\% to $20 \%$ ) to $\mathrm{HW}$ (5\% to $7 \%$ ) and constant throughout the sampling period. According to the Pejrup diagram, the flat was characterized by very high hydrodynamics at LW to moderate hydrodynamics at HW and MW. Consequently, silt and clay were deposited at MW and HW on the flat.

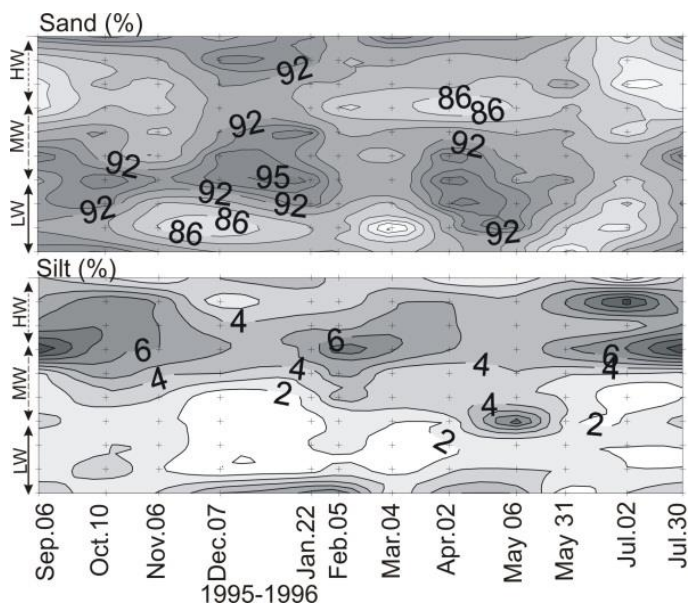

Fig. 3. Percentage (\%) of sand and silt along the intertidal profile (HW; MH; LW) at Rasa da Cotinga island (1995/1996).

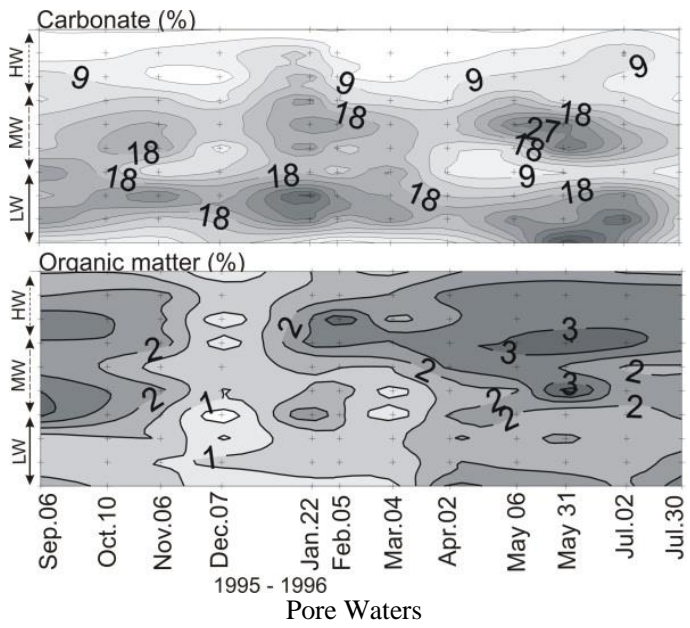

Fig. 4. Percentage (\%) of carbonate and organic matter along the intertidal profile (HW; MH; LW) at Rasa da Cotinga island (1995/1996). 
The temperature of the pore water of the sediments increased from September $\left(18.5^{\circ} \mathrm{C} \pm 0.5^{\circ} \mathrm{C}\right)$ to December $\left(29.0^{\circ} \mathrm{C} \pm 0.5^{\circ} \mathrm{C}\right)$, maintaining the high values during summer, followed by a decrease continuing to July $\left(14.2^{\circ} \mathrm{C} \pm 0.3^{\circ} \mathrm{C}\right)$ (Fig. 5). Temperature showed negative correlation with salinity $(\mathrm{r}=0.54)$ and positive correlation with rain $(\mathrm{r}=0.62)$. The salinity oscillated from $23.3 \pm 0.3$ (November) to $33.7 \pm 0.6$ (July) (Fig. 5). The temperature and salinity presented no spatial differences on the different sampling dates, reflecting their homogeneity during periods of intertidal flat immersion.
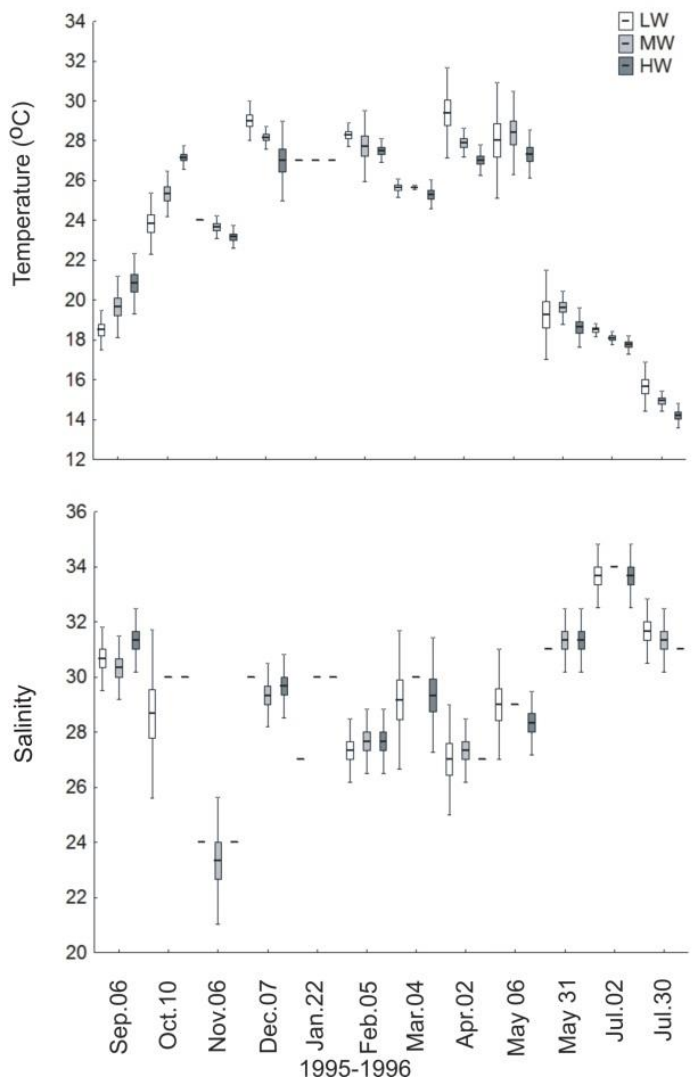

Fig. 5. Mean \pm SD of temperature $\left({ }^{\circ} \mathrm{C}\right)$ and salinity along the intertidal profile (HW, MH, LW) at Rasa da Cotinga island (1995/1996).

The concentration of DIN showed the same seasonal pattern in the pore water of both the MW and HW areas (Fig. 6). DIN concentrations were higher in November, $19.8 \pm 15.8 \mu \mathrm{M}$ for $\mathrm{MW}$ and $37.2 \pm 19.3$ $\mu \mathrm{M}$ for HW. The lower mean concentration occurred in winter (July) for both MW $(1.4 \pm 0.7 \mu \mathrm{M})$ and HW (1.7 $\pm 0.3 \mu \mathrm{M})$. LW showed higher DIN concentrations in spring $(30.6 \pm 16.3 \mu \mathrm{M}$, September), which decreased in the winter when the lowest concentration was observed $(0.9 \pm 0.3 \mu \mathrm{M}$, May). Ammonium was the main form of DIN in the interstitial water of the flat, representing from $80 \%$ (LW) to $86 \%$ (HW) of this pool. The concentration of dissolved inorganic phosphorus (DIP) was homogeneous in the flat at each campaign and showed the same seasonality as the DIN (Fig. 7). Higher concentrations were observed from September to April with an extreme of $6.6 \pm 4.8 \mu \mathrm{M}$ on the MW (March). In winter, the DIP concentrations were lower than 0.9 $\mu \mathrm{M}$, the minimum value occurring on HW in July $(0.5$ $\pm 0.0 \mu \mathrm{M})$. NP ratios were from 1 to 87 , though $78 \%$ of the data were less than 10 and only $15 \%$ were in accordance with the Redfield ratios. The DIP concentration showed significant positive correlation only with rainfall $(\mathrm{r}=0.36 ; \mathrm{p}<0.000)$. The DIN was not correlated with any variable.

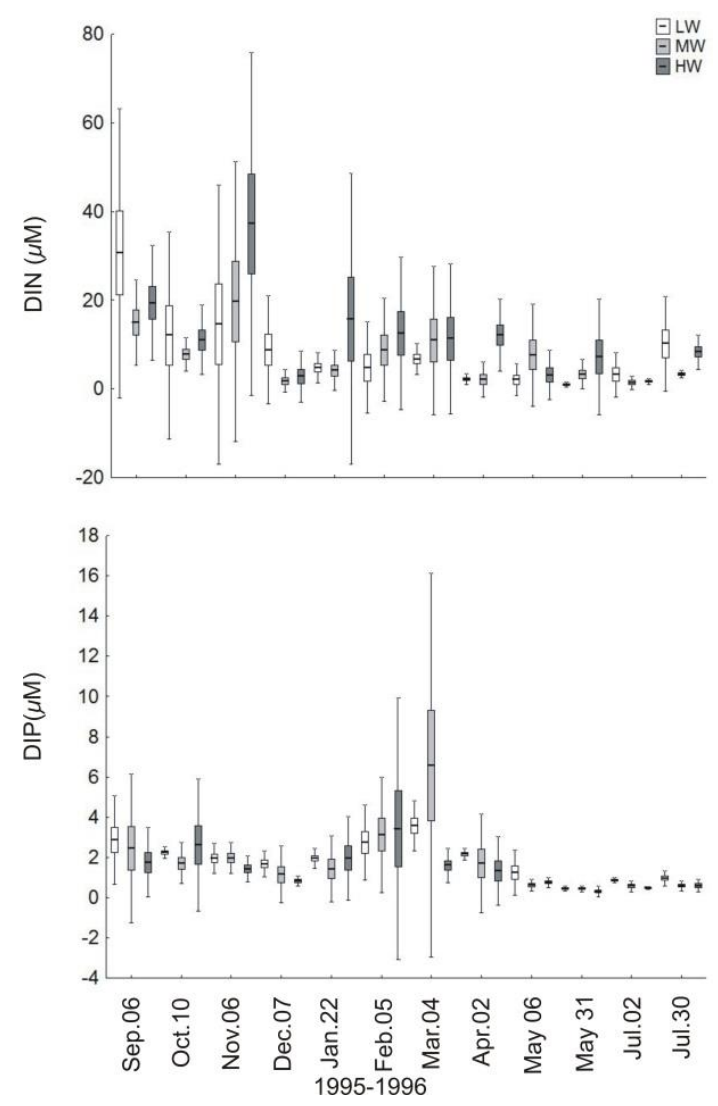

Fig. 6. Mean \pm SD of Dissolved Inorganic Nitrogen $(\mu \mathrm{M})$ and Dissolved Inorganic Phosphorus $(\mu \mathrm{M})$ concentrations along the intertidal profile (HW, MH, LW) at Rasa da Cotinga island $(1995 / 1996)$.

Microphytobenthos Biomass

Chlorophyll- $a$ (Chl- $a$ ) concentration in the flat sediment showed a clear spatial gradient (Fig. 7); 
lower concentrations were detected on LW and increasing concentrations found at the MW and HW sites. The Chl- $a$ concentration oscillated from $6.2 \pm$ $1.9 \mu \mathrm{g} . \mathrm{gsed}^{-1}$ (LW, December 1995) to $38.2 \pm 17.6$ $\mu \mathrm{g} . \mathrm{gsed}^{-1}$ (HW, May 1996). A Pearson correlation indicated that clay $(\mathrm{r}=0.36 ; \mathrm{p}<0.05)$, organic matter $(r=0.39 ; p<0.05)$ and carbonate $(r=-0.44 ; p<0.05)$ contents in the sediment were correlated with Chl- $a$. Seasonally, Chl- $a$ concentration decreases from November to February, followed by an increase until July. The spatial and seasonal distribution of phaeophytin- $a$ (Phae- $a$ ) concentrations were quite similar to those of Chl- $a$ (Fig. 7) on the flat, showing a good significant and direct correlation $(r=0.73$; $\mathrm{p}<$ 0.001 ). Phae-a concentration in the flat oscillated from $1.2 \pm 0.1 \mu \mathrm{g} . \mathrm{gsed}^{-1}(\mathrm{LW}$, December 1995) to $18.6 \pm$ $13.9 \mu \mathrm{g} . \mathrm{gsed}^{-1}$ (HW, May 1996). The Chl- $a$ to Phae- $a$ pigment mean ratio was $4 \pm 1$ on the flat and spatially increased from the HW to the LW sites. In $50 \%$ of the observations, the Chl- $a$ concentration was twice as high as that of phaeophytin- $a$.

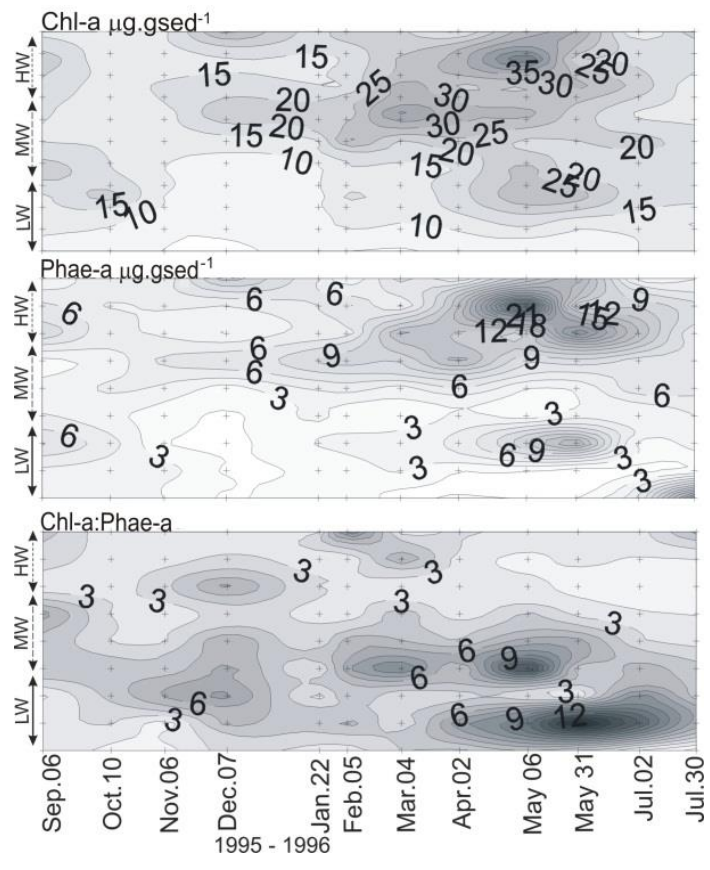

Fig. 7. Contents of chlorophyll-a ( $\mu \mathrm{g} \cdot \mathrm{g}^{-1}$ dry sed) and phaeophytin- $a$ ( $\mu \mathrm{g} . \mathrm{g}^{-1}$ dry sed) and chlorophylla:phaeophytin- $a$ (Chl- $a$ :Phae- $a$ ) ratio in the sediment along the intertidal profile (HW, MH, LW) at Rasa da Cotinga island (1995/1996).

Environmental Influence on Microphytobenthic Biomass

PCA analysis of biotic and abiotic data represents $49 \%$ of total data variance (Fig. 8). Axis 1 relates to the spatial variability within the data that separates the samples of the LW from those of the other flat zones (MW and HW). Chlorophyll- $a$ and phaeophytin-a concentrations, the NP ratio and the sediment characteristics (organic matter, clay and silt contents) presented the highest positive loads on axis 1 , being related to the upper flat. Gravel and carbonate contents in the sediment showed the highest negative loads on this axis, being related to the lower flat. Axis 2 indicated the temporal trend of the data and represents $21 \%$ of total data variance. Spring samples were separated from the winter ones along axis 2 which was mainly associated with temperature, nitrogen, phosphate and salinity pore water, together with organic matter and sand content in the sediments.

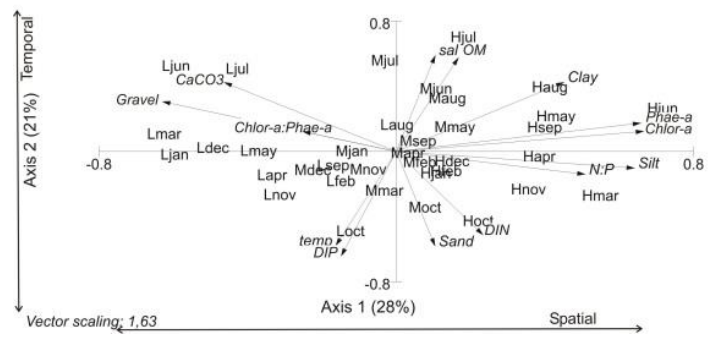

Fig. 8. Principal Component Analysis (PCA) showing microphytobenthic biomass in relation to environmental variables. Samples distinguished according to spatial and temporal trends. Gravel; Clay; Sand; $\mathrm{CaCO}_{3}=$ carbonate; Chlor- $a$ :Phae- $a=$ chorophyll- $a$ and phaeophytin- $a$ ratio; Sal $=$ salinity; $\mathrm{OM}=$ organic matter; Chlor $-a=$ chorophyll $-a$; Phae $-a=$ phaeophytin- $a$; DIP $=$ dissolved inorganic phosphorus; DIN = dissolved inorganic nitrogen; N:P = NID and DIP ratio; temp $=$ temperature.

\section{DisCUSSION}

\section{Spatial Distribution}

The sediment characteristics explained the microphytobenthic biomass distribution along the intertidal flat of Rasa da Cotinga island. Through deposition and suspension processes, sediment particles are distributed in the environment in relation to their size and weight. The tidal flat zonation tends to be a response of the sediment characteristics (DYER, 2000). The sediment at the LW high energy site was characterised by high gravel and carbonate content, the latter consisting mainly of shell fragments. In contrast, silt, clay and organic matter content accumulated in the sediments of the more sheltered MW and HW sites closer to the shore, where the microphytobenthic biomass was higher. We observed that during high tide, waves broke and dissipated their energy in the saltmarshes and mangrove sites, beyond the HW. During the ebb tide, the area near LW 
suffered from the breaking waves and possibly this turbulence prevents the settling of fine particles and microalgae. The lower hydrodynamics of the middle and upper flat areas favour the deposition of fine suspended matter and the stability of the sediment, both important factors for microphytobenthos development. Furthermore, the microphytobenthic primary production was higher at the MW and HW sites than at the LW site and this difference was determined mainly by incident radiation (FONSECA et al., 2008). The constant scouring of the sediment, including microphytobenthic cells and the low light incidence might explain the lower microphytobenthic biomass at the LW, as observed by others (UNDERWOOD and PATERSON, 1993; BLANCHARD et al., 2000). It is important to note that aerial desiccation, which limits the microphytobenthos biomass (PINCKNEY and ZINGMARK, 1993; UNDERWOOD and PATERSON, 1993; BROTAS et al., 1995), was not predominant in the flat area studied. The MW presented a concave horizontal profile and was submerged on all the sampling dates. The HW and LW areas presented many bed forms that provide water and particulate matter and favor microphytobenthic biomass accumulation.

Intertidal areas are highly physically dynamic and the chlorophyll- $a$ degradation product, phaeophytin- $a$, might be a result of photo-oxidation, reworking of the sediment by macrofauna and grazing activity (GALOIS et al., 2000; CARTAXANA et al., 2006; BLANCHARD et al., 2001). The sediment is an important site for the degradation of organic matter, including the microphytobenthic biomass. However, chlorophyll- $a$ was twice as high as phaeophytin- $a$ during this study, which suggests that the increment of microphytobenthic biomass more than compensated for the effects of the degradation processes and resulted in the good physiological condition of this community (FORD and HONEYWILL, 2002). Spatially, the general seaward increase in the chlorophyll- $a$ :phaeophytin- $a$ ratio suggested a preferential accumulation of phaeopigment at the sheltered sites of the middle and upper flat. This tendency might be a result of: i) the weaker hydrodynamics and deposition characteristic of the upper mudflat; ii) higher herbivory, considering the higher macrofaunal density at the HW and MW sites (PAGLIOSA and LANA, 2005; BOEHS et al., 2004), and iii) degraded products from the saltmarsh and mangrove swamps which bordered the study site.

Seasonality

The Brazilian Subtropical Zone has a clear seasonality with a rainy period occurring during spring-summer and a dry season during autumnwinter, when the winds are stronger due to the passage of cold fronts (MACHADO et al., 1997). However, in
December/1995-January/1996, the South Atlantic Convergence Zone (SACZ) was more intense and this favored the development of cold-fronts (BARREIRO et al., 2002). Under such circumstances, stronger southerly winds above $6 \mathrm{~m} \cdot \mathrm{s}^{-1}$ are registered, as observed on December 29th 1995, which is enough to disrupt the microphytobenthic layer (UNDERWOOD and PATERSON, 1993; DE JONGE and VAN BEUSEKMAN, 1995). The persistence of these winds can, further, cause meteorological tides (CAMPOS et al., 2010), increasing the height of the sea's surface and confining water in Paranaguá Bay (CAMARGO and HARARI, 1994). This confinement was observed during the January sampling at the astronomical ebb tide when the intertidal flat of Rasa da Cotinga island remain covered by a shallow water column $(15 \mathrm{~cm}$ depth). Turbulence generated by the strong winds destabilised both the microphytobenthic community and the sediment, decreasing the organic matter and fine grain content (DE JONGE and VAN BEUSEKMAN, 1995; LUCAS et al., 2000). Rasa da Cotinga island faces south; consequently, the winds from this quadrant arrive without any modification of speed or direction, reinforcing the hypothesis that the wind might have been an important factor in controlling the microphytobenthic biomass. In addition, the temperature and salinity measured in November 1995 were lower than the averages observed in the spring-summer season (BRANDINI et al., 2001; MARONE et al., 2005). These minima may have been favoured by the heavy rainfall - of around $103 \mathrm{~mm}$ - which occurred during the month preceding this sampling. Under such conditions, the seston concentration increases in surface water, diminishing the photic zone (BRANDINI and REBELLO, 1990; MIZERKOWSKI et al., 2012) and limiting the development of the microphytobenthos (FONSECA et al, 2008).

From February to March 1996, the formation of a thick mucilaginous film was observed on the sediment surface of the upper and middle flat, which extended into the lower flat until May. Concomitantly, the organic matter, fine material and chlorophyll- $a$ content on the sediment surface increased. Microscopic analysis showed that this film was formed particularly of the diatom Nitzchia sigma, which produces a great concentration of extracellular mucopolysaccharides (UNDERWOOD and SMITH, 1998). Diatom mats are common phenomena on intertidal mudflats (MCINTYRE and CULLEN, 1995) and their effects on sediment characteristics, especially the stabilisation of sediments, has been described for both muddy and sandy sediments (BLANCHARD et al., 2000; RIETHMÜLLER et al., 2000; STAL, 2003; STAL, 2010). DE BROUWER et al. (2000) and DE BROUWER et al. (2003) observed the influence of the microphytobenthos on the sedimentation process when 
correlating the biomass of this community with fine sediment deposition. In this study, the positive correlation between the fine content of sediment and the Chl- $a$ concentration was evident. This suggests that the microphytobenthic biofilm was efficient in stabilising the sediment, by binding fine-grained sediments through the mucilage of diatom mats. Additionally, the wind speed and the hydrodynamic regime decreased from March to May, providing depositional conditions and a positive feedback between biology and sedimentology.

Nutrients may not limit the growth of the microphytobenthos community because their concentrations are usually high in the interstitial waters of the tidal flats (BROTAS et al., 1995). However, growth limitation by $\mathrm{N}$ and $\mathrm{P}$ has been indicated through the analyses of the NP ratio (PINCKNEY et al., 1995; HILLEBRAND and KAHLERT, 2002). An NP ratio from 10 to 20 has been considered ideal for marine microalgae development (KOCUM et al., 2002). Even though the nutrient concentrations were, on average, three times higher in the pore water of the studied intertidal flats than those found in the water of Paranaguá Bay (KNOPPERS et al., 1987; BRANDINI and REBELLO, 1990; MACHADO et al., 1997), NP ratios below 10 were observed in $78 \%$ of our samples. This indicates that the microphytobenthos could be limited by nitrogen at our study site and PCA analysis was able to show this because the NP ratio is related, on axis 1 , to the microphytobenthic biomass.

The seasonal dynamics of pore water nutrients could be associated with water circulation and microphytobenthos uptake on the intertidal flats of Rasa da Cotinga island. During early January, strong winds kept the particulate organic material in suspension, decreasing sedimentation and accumulation of this material on the tidal flat. After this turbulent period, the amount of detritus increased in the sediment, favoured by the sedimentation of autochthonous and allochthonous suspended material, which was intensified by the continental runoff observed during April and May 1996. FONSECA et al. (2008) has estimated high mineralisation rates in April and May 1996 at the water-sediment interface of the same tidal flat. This suggests the rapid decomposition of organic matter accumulated in the sediments during this rainy period and the enrichment of the nutrients in the pore water of the sediments. The higher microphytobenthic biomass and the consequent uptake of nutrients by this community, might explain the decrease of pore water DIN and DIP concentrations from March to May.

After May, the temperature decreased to a minimum of $14^{\circ} \mathrm{C}$ and the NP ratios and dissolved inorganic nutrient concentrations remained unfavourable for algal development. Moreover, the photosynthetic radiation that reached the sediment of this intertidal flat was considered important for the decrease of microphytobenthic photosynthesis during winter 1996 (FONSECA et al., 2008). These characteristics appear to have limited the development of microphytobenthos when the hydrodynamic conditions were favourable.

\section{Conclusions}

The spatial and seasonal dynamics of the microphytobenthic community on the tidal flats of the euhaline sector of Paranaguá Bay are mainly dominated by physical processes. Strong southerly winds and meteorological tides generated an excessive turbulence, which might be responsible for the remarkable structural changes in the benthic community; the development of the microphytobenthic biomass of the sediment decreased. Under favourable hydrodynamic conditions for sedimentation, the microphytobenthos community formed a visible mucilaginous layer, retaining fine sediments and increasing sediment stabilization on the flat. Under these conditions, the variability of the microphytobenthos community was determined by the nitrogen concentration and temperature of the interstitial water.

\section{ACKNOWLEDGEMENTS}

This study was developed during the Master's degree course of A.L. Fonseca in the Botany Postgraduate Department of the Universidade Federal do Paraná. We would like to thank $\mathrm{CNPq}$ for providing the Master's scholarship, Centro de Estudos do Mar for their logistic support and the anonymous referees for suggestions for the improvement of the paper.

\section{REFERENCES}

ALONGI, D. The ecology of tropical soft-bottom benthic ecosystems. Oceanogr. Mar. Biol. Ann. Rev., v. 20, p. 381-496, 1990.

BARREIRO, M.; CHANG, P.; SARAVANAN, R. Variability of the south Atlantic Convergence Zone simulated by an atmospheric general circulation model. J. Clim., v. 15, p. 745-763, 2002.

BIGARELLA, J. J.; BECKER, R. D.; MATOS, D. J.; WERNER, A. A Serra do Mar e a porção oriental do estado do Paraná. Curitiba: Secretaria do Estado do Planejamento do Governo do Paraná, ADEA, 1978. 248 p.

BLANCHARD, G. F.; GUARINI, J. M.; ORVAIN, F.; SAURIAU, P. Dynamic behaviour of benthic microalgal biomass in intertidal mudflats. J. Exp. Mar. Biol. Ecol., v. 264 , p. $85-100,2001$. 
BLANCHARD, G. F.; PATERSON, D. M.; STAL, L. J.; RICHARD, P.; GALOIS, R.; HUET, V.; KELLY, J.; HONEYWILL, C.; DE BROUWER, J.; DYER, K.; CHRISTIE, M.; SEGUIGNES, M.; The effect of geomorphological structures on potential biostabilisation by microphytobenthos on intertidal mudflats. Cont. Shelf Res., v. 20, p. 1243-1256, 2000.

BOEHS, G.; ABSHER, T. M.; CRUZ-KALED, A. C. Composition and distribution of benthic mollusks on intertidal flats of Paranaguá Bay (Paraná, Brazil). Sci. Mar., v. 68, p. 537-543, 2004.

BRANDINI, F. P.; REBELLO, J. Variação temporal de parâmetros hidrográficos e material particulado em suspensão em dois pontos fixos da Baia de Paranaguá, Paraná (junho/87 - fevereiro/88). Nerítica, v. 5, p. 95$111,1990$.

BRANDINI, F. P.; PELLIZARI, F. M.; FERNANDES, L. F.; FONSECA, A. L. Production and biomass accumulation of periphytic diatoms growing on glass slides during a year cycle in a coastal subtropical environment (Bay of Paranaguá, southern Brazil). Mar. Biol., v. 138, p. 163$171,2001$.

BROTAS, V.; CABRITA, T.; PORTUGAL, A.; SERÔDIO, J.; CATARINO, F. Spatio-temporal distribution of the microphytobenthic biomass in intertidal flats of Tagus estuary (Portugal). Hydrobiologia, v.300/301, p.93-104, 1995.

CAMARGO, M. G. Sysgran: um sistema e código aberto para análise granulométrica do sedimento. Rev. Bras. Geocienc., v.3 6, p. 371-378, 2006.

CAMARGO, R.; HARARI, J. Modelagem numérica de ressacas na plataforma sudeste do Brasil a partir de cartas sinóticas de pressão atmosférica na superfície. Bol. Inst. Oceanogr. (Univ. São Paulo), v. 42, p. 19-34, 1994.

CAMPOS, R. M.; CAMARGO, R.; HARARI, J. Caracterização de eventos extremos do nível do mar em Santos e sua correspondência com as reanálises do modelo do NCEP no sudoeste do Atlântico sul. Rev. Bras. Meteorol., v. 25, p. 175-184, 2010.

CARTAXANA, P.; MENDES, C. R.; VAN LEEUWE, M. A.; BROTAS, V. Comparative study on microphytobenthic pigments of muddy and sandy intertidal sediments of the Tagus estuary. Estuarine, Coastal Shelf Sci., v. 66, p. 225-230, 2006.

CHOY, E. J.; AN, S.; KANG, C. K. Pathways of organic matter through food webs of diverse habitats in the regulated Nakdong River estuary (Korea). Estuarine, Coastal Shelf Sci., v. 78, p. 215-226, 2008.

DE BROUWER, J. F. C.; BJELIC, S.; DE DECKERE, E. M. G. T.; STAL, L. J. Interplay between biology and sedimentology in a mudflat (Biezelingse Ham, Westerschelde, the Netherlands). Cont. Shelf Res., v. 20, n. 10/11, p. 1159-1177, 2000 .

DE BROUWER, J. F. C.; DE DECKERE, E. M. G. T.; STAL, L. J. Distribution of extracellular carbohydrates in three intertidal mudflats in Western Europe. Estuarine Coastal Shelf Sci., v. 56, p. 313-324, 2003.

DE JONGE, V. N.; VAN BEUSEKMAN, J. E. E. Wind- and tide-induced resuspension of sediment and microphytobenthos from tidal flats in the Ems estuary. Limnol. Oceanogr., v. 40, p. 766-778, 1995.

DU, G. Y.; SON, M.; AN, S.; CHUNG, I. K. Temporal variation in the vertical distribution of microphytobenthos in intertidal flats of the Nakdong River estuary, Korea. Estuarine, Coastal Shelf Sci., v. 86, p. 62-70, 2010.

DYER, K. R.; CHRISTIE, M. C.; WRIGHT, E. W. The classification of intertidal mudflats. Cont. Shelf Res., v. 20, p. 1039-1060, 2000.

FLEMMING, B. W. A revised textural classification of gravel-free muddy sediments on the basis of ternary diagrams. Cont. Shelf Res., v. 20, p. 1125-1137, 2000.

FONSECA, A.; BRANDINI, N.; MACHADO, E. C.; BRANDINI, F. P. Variação especial e sazonal da produção primária microfitobêntica em uma planície entremarés subtropical, Baía de Paranaguá, ParanáBrasil. Insula, v. 37, p. 19-34, 2008.

FORD, R. B., HONEYWILL, C. Grazing on intertidal microphyto- benthos by macrofauna: is pheophorbide a useful marker? Mar. Ecol. Prog. Ser., v. 229, p. 33-42, 2002.

GALOIS, R.; BLANCHARD, G.; SEGUIGNES, M.; HUET, V.; JOASSARD, L. Spatial distribution of sediment particulate organic matter on two estuarine intertidal mudflats: a comparison between Marennes-Oleron Bay (France) and the Humber estuary (UK). Cont. Shelf Res., v. 20, p. 1199-1217, 2000.

GRASSHOFF, K.; EHRHARDT, M.; KREMLING, K. Methods of seawater analysis. 2.ed. Weinheim: Verlag Chemie, 1983. 419 p.

HERMAN, P. M. J.; MIDDLEBURG, J. J.; WIDDOWS, J.; LUCAS, C. H.; HEIP, C. H. R. Stable isotopes as trophic tracers: combining field sampling and manipulative labelling of food resources for macrofauna. Mar. Ecol. Prog. Ser., v. 204, p. 79-92, 2000.

HILLEBRAND, H.; KAHLERT, M. Effect of grazing and water column nutrient supply on biomass and nutrient content of sediment microalgae. Aquat. Bot., v. 72, p. 143-159, 2002.

KNOPPERS, B.; BRANDINI, F. P.; THAMM, C. A. Ecological studies in the Bay of Paranaguá. II. Some physical and chemical characteristics. Nerítica, v. 2, p. 1-36, 1987.

KOCUM, E.; NEDWELL, D. B.; UNDERWOOD, G. J. C. Regulation of phytoplankton primary production along a hypernutrified estuary. Mar. Ecol. Prog. Ser., v. 231, p. 13-22, 2002.

LUCAS, C. H.; WIDDOWS, J.; BRINSLEY, M. D.; SALKELD, P. N.; HERMAN, P. M. J. Benthic-pelagic exchange of microalgae at a tidal flat. 1. Pigment analysis. Mar. Ecol. Prog. Ser., v. 196, p. 59-73, 2000.

MACHADO, E. C., DANIEL, C. B., BRANDINI, N., QUEIROZ, R. L. V. Temporal and spatial dynamics of nutrients and particulate suspended matter in the Bay of Paranaguá, PR, Brazil. Nerítica, v. 11, p. 17-36, 1997.

MANTOVANELLI, A.; MARONE, E.; SILVA, E. T.; LAUTERT, L. F. C.; KLINGENFUSS, M. S.; PRATA Jr., V. P.; NOERNBERG, M. A.; KNOPPERS, B. A.; ANGULO, R. J. Combined tidal velocity and duration asymmetries as a determinant of water transport and residual flow in Paranaguá Bay estuary. Estuarine, Coastal Shelf Sci., v. 59, p. 523-537, 2004.

MARONE, E.; CAMARGO, R. Marés meteorológicas no litoral do Estado do Paraná: o evento de 18 de agosto de 1993. Nerítica, v. 8, n. 1/2, p. 73-85, 1994. 
MARONE, E.; MACHADO, E. C.; LOPES, R. M.; SILVA, E. T. Land-ocean fluxes in the Paranaguá Bay Estuarine System. Braz. J. Oceanogr., v. 53, n. 3/4, p. 169-181, 2005.

MCINTYRE, H. L.; CULLEN, J. J. Fine-scale vertical resolution of chlorophyll and photosynthetic parameters in shallow-water benthos. Mar. Ecol.: Prog. Ser., v. 122, p. 227-237, 1995.

MIDDELBURG, J. L.; BARRANGUET, C.; BOSCHKER, H. T. S.; HERMAN, P. M. J.; MOENS, T.; HEIP, C. H. $\mathrm{R}$. The fate of intertidal microphytobenthos carbon: an in situ 13C-labeling study. Limnol. Oceanogr., v. 45, p. 1224-1234, 2000.

MIZERKOWSKI, B. D.; HESSE, K. J.; LADWIG, N.; MACHADO, E. C.; ROSA, R. A.; ARAÚJO, T. G.; $\mathrm{KOCH}$, D. Sources, loads and dispersion of dissolved inorganic nutrients in Paranaguá Bay. Ocean Dynamics, v. 62, n.10/12, p. 1409-1424, 2012.

NOERNBERG, M., LAUTERT, L. F. C.; ARAUJO, A. D.; MARONE, E.; ANGELOTTI, R.; NETTO Jr., J. P. B.; KRUG, L. A. Remote sensing and GIS integration for modelling the Paranaguá Estuarine Complex, Brazil. J. Coastal Res., v. 39, p. 1627-1631, 2006.

MUROLO, P. P. A.; CARVALHO, P. V. V. C.; CARVALHO, M. L. B.; SOUZA-SANTOS, L. P.; SANTOS, P. J. P. Spatio-temporal variations of microphytobenthos in the Botafogo and Siri estuaries (Northeast - Brazil). Braz. J. Oceanogr., v. 54, p. 19-30, 2006.

PAGLIOSA, P. R.; LANA, P. C. Impact of plant cover removal on macrobenthic community structure of a subtropical salt marsh. Bull. Mar. Sci., v. 77, n. 1, p. 1$18,2005$.

PEJRUP, M. The triangular diagram used for classification of estuarine sediments: a new approach. In: BOER, P.L.; GELDER, A.V.; NIO, S.D. (Eds.). Tide-influenced sedimentary environments and facies. Dordrecht: D. Reidel, 1988. 544 p. [Symposium on Classic Tidal Deposits, Utrecht, 1985].

PINCKNEY, J.; PEARL, H.; FITZPATRICK, M. The impacts of seasonality and nutrients on microbial mat community structure and function. Mar. Ecol.: Prog. Ser., v. 123, p. 207-216, 1995.

PINCKNEY, J. L.; ZINGMARK, R. G. Modelling the annual production of intertidal benthic microalgae in estuarine ecosystems. J. Phycol., v. 29, p. 396-407, 1993.

PLANTE-CUNY, M. R. Pigments photosynthétiques et production primaire des fonds meubles néritiques d'une région tropicale (Nosy-Bé, Madagascar). Paris: Éditions de l'Office de la recherche scientifique et technique outre-mer ORSTOM, 1978. p. 1-35 (Travaux et Documents de l'ORSTOM; 96.
REISE, K. Grazing on sediment shores. In: JOHN, D. M.; HAWKINS, S. J.; PRICE, J. H. (Eds.). Plant-animal interactions in the marine benthos. Oxford: Clarendon Press, 1992. p.133-145. (Systematics Association Special; v. 46).

REISE, K. Tidal flat ecology: an experimental approach to species interactions. Berlin: Springer-Velag, 1985. $191 \mathrm{p}$. (Ecological studies; v. 54).

RIETHMÜLLER, R.; HEINEKE, M.; KÜHL, H.; KEUKERRÜDIGER, R. Chlorophyll a concentration as an index of sediment stabilization by microphytobenthos? Cont. Shelf Res., v. 20, p. 1351-1372, 2000.

SANTOS, P. J. P.; CASTEL, J.; SOUZA-SANTOS, L. P. Microphytobenthic patches and their influence on meiofaunal distribution. Cah. Biol. Mar., v. 36, p. 133139, 1995.

STAL, L. J. Microphytobenthos, their extracellular polymeric substances, and the morphogenesis of intertidal sediments. Geomicrobiol. J., v. 20, p. 463-478, 2003.

STAL, L. J. Microphytobenthos as a biogeomorphological force in intertidal sediment stabilization. Ecol. Eng. J., v. 36, p. 236-245, 2010.

SUGUIO, K. Introdução à sedimentologia. São Paulo: EDUSP, Edgard Blücher, 1973. 318 p.

UNDERWOOD, G. J. C.; PATERSON, D. M. Seasonal changes in diatom biomass, sediment stability and biogenic stabilization in the Severn estuary. J. Mar. Biol. Assoc. U. K., v. 73, p. 871-887, 1993.

UNDERWOOD, G. J. C., SMITH, D. J. Predicting epipelic diatom exopolymer concentrations in intertidal sediments from sediment chlorophyll a. Microb. Ecol., v. 35, p. 116-125, 1998

WELKER, C., SDRIGOTTI, E., COVELLI, S., FAGANELI, J. Microphytobenthos in the Gulf of Trieste (northern Adriatic Sea): relationship with labile sedimentary organic matter and nutrients. Estuarine, Coastal Shelf Sci., v. 55, p. 259-273, 2002.

YAMAGUCHI, H.; MONTANI, S.; TSUTSUMI, H.; HAMADA, K.; UEDA, N.; TADA, K. Dynamics of microphytobenthic biomass in a coastal area of western Seto Inland Sea, Japan. Estuarine, Coastal Shelf Sci., v. 75, p. 423-432, 2007.

(Manuscript received 27 October 2010; revised 14 April 2013; accepted 07 May 2013) 